\title{
Meningkatkan Kemampuan Strategi Pemasaran dengan Menggunakan Teknologi Informasi Pada Bisnis Perhotelan di kota Batam
}

\author{
Daniel Apdianto Herman \\ email: daniel.herman@uib.ac.id \\ Universitas Internasional Batam
}

\begin{abstract}
Abstrak
Pembangunan bisnis perhotelan di Batam semakin membuat ketatnya persaingan dan kompetisi di antara hotel hotel. Persaingan dan kompetisi tersebut membuat manajemen dari hotel-hotel harus memiliki kemampuan strategi pemasaran yang baik sehingga dapat meningkatkan volume penjualan dan tingkat hunian kamar dari bisnis perhotelan mereka. Tujuan dari penelitian ini adalah untuk mengetahui bagaimana teknologi informasi dapat meningkatkan kemampuan strategi pemasaran di lihat dari volume penjualan dan tingkat hunian kamar pada bisnis perhotelan. Metode pengambilan sampel penelitian ini dilakukan dengan menggunakan purposive sampling dengan jumlah responden sebanyak 50 orang yang diambil secara sengaja. Alat analisis yang digunakan adalah Analisis SWOT untuk memanfaatkan peluang dan memaksimalkan kekuatan, menguranig kelemahan serta menghindari ancaman. Strategi SO yang diterapkan dengan menggunakan brand positioning melalui pengembangan situs web hotel, memaksimalkan kerjasama dengan travel agent dengan memberikan kemudahan booking menggunakan aplikasi teknologi secara online. Pada strategi ST, diterapkan dengan melakukan analisa perbandingan dari kualitas kamar dan harga kamar dengan hotel sekelas sesuai bintang melalui teknologi informasi, menggunakan media promosi dengan di dukung kemajuan teknologi. Pada strategi WO dengan meminimalkan kelemahan dengan melakukan analisis komponen biaya, melakukan renovasi kamar dengan di tunjang penggunaan teknologi informasi. Kemudian pada strategi WT yang dilakukan adalah melalukan peningkatan kualitas pelayanan dengan menggunakan mobile checkin.
\end{abstract}

Kata kunci : Strategi Pemasaran, Analisis SWOT, Volume Penjualan, Tingkat Hunian Kamar

\section{Pendahuluan}

Bisnis perhotelan merupakan salah satu faktor industri yang memiliki peranan penting dalam perkembangan pariwisata di Indonesia. Jumlah kunjungan wisatawan baik mancanegara maupun wisatawan dalam negeri yang mengalami peningkatan akan sangat berpengaruh pada perkembangan bisnis perhotelan dikarenakan dengan meningkatnya jumlah kunjungan wisatawan akan meningkatkan pula kebutuhan dari jasa akomodasi khususnya bisnis perhotelan sebagai sarana penunjang.

Meningkatnya perekonomian di Indonesia diikuti juga dengan pembangunan dan berkembangnya fasilitas-fasilitas penunjang kebutuhan masyarakat, salah satunya adalah terus bertambahnya jumlah hotel di Indonesia. Hotel merupakan jenis industri yang menghasilkan dan menyediakan sesuatu dalam bentuk barang dan jasa yang tidak hanya menjual produk yang berwujud tetapi juga menjual produk yang tidak berwujud seperti dalam bentuk pelayanan, hiburan, suasana atau lingkungan yang nyaman, bersih dan indah. Menurut Peraturan Menteri Pariwisata dan Ekonomi Kreatif tentang standar usaha hotel, usaha hotel adalah usaha penyedia akomodasi berupa kamar-kamar di dalam suatu bangunan, yang dapat dilengkapi dengan jasa pelayanan makan dan minum, kegiatan hiburan dan/ atau fasilitas lainnya secara harian dengan tujuan memperoleh keuntungan.

Internet sebagai sumber informasi utama dalam industri pariwisata turut mempengaruhi business model dari aspek pariwisata terutama dalam industri perhotelan dan jasa transportasi.

Persaingan bisnis saat ini telah mendorong para pengelola bisnis (maupun calon pelaku bisnis) untuk bergerak cepat, kreatif dan antisipatif. Hal ini disebabkan oleh perubahan mendasar dalam sistem persaingan bisnis yang memanfaatkan teknologi. Perubahan tersebut meliputi sistem perdagangan, cara bertransaksi, sistem pemasaran maupun sistem pembayaran (Widiyanto et al, 2015). Terutama pada perusahaan yang bergerak di bidang pariwisata

Berdasarkan permasalahan yang telah disampaikan di atas, maka tujuan penelitian ini adalah untuk meningkatkan kemampuan 
strategi pemasaran melalui penggunaan teknologi informasi pada binsis perhotelan di kota Batam.

\section{Metode Penelitian}

Penelitian ini hendak melakukan analisis terhadap strategi pemasaran menggunakan teknologi informasi yang dilakukan oleh hotel-hotel di kota Batam dengan menggunakan analisis SWOT. Sumber data yang digunakan adalah kuesioner yang diisi oleh karyawan ataupun pihak yang mengenal strategi pemasaran hotel-hotel tersebut. Data yang diperoleh dari kuesioner dalam bentuk bobot dan rating ditabulasikan sehingga diperoleh dasar penentuan strategi pemasaran menggunakan teknologi informasi untuk meningkatkan volum penjualan dan tingkat hunian kamar pada hotel hotel di kota Batam.

Penelitian ini menggunakan judgement sampling yang termasuk dalam purposive sampling dengan memilih anggota sampel berdasarkan keperluan penelitian dan responden adalah orang - orang yang mengerti benar keadaan hotel yang diteliti baik internal maupun eksternal. Sampel yang diambil berjumlah 50 orang responden yang meliputi seluruh staff berbagai departemen dari hotel-hotel di kota Batam.

Kuesioner yang akan digunakan terdiri dari empat bagian dengan 14 indikator internal dan 9 indikator eksternal. Dua angket meminta responden untuk memberi bobot dan dua angket lainnya responden diminta untuk memberi rating. Teknik analisis data yang dipergunakan adalah analisis SWOT, yaitu analisis yang mengidentifikasikan berbagai faktor secara sistematis untuk merumuskan suatu strategi perusahaan. Analisis ini didasarkan pada logika yang dapat memaksimalkan kekuatan (strengths), dan peluang (opportunities), namun secara bersamaan dapat meminimalkan kelemahan (weaknesses) dan ancaman (threats).

Untuk lingkungan internal, memberikan gambaran tentang kekuatan dan kelemahan perusahaan. Bila nilai yang diperoleh baik dan sangat baik diidentikan dengan kekuatan, kurang baik dan sangat kurang baik diidentikan dengan kelemahan.

$$
\text { Untuk lingkungan eksternal, }
$$
memberikan gambaran tentang peluang dan ancaman. Apabila nilai yang diperoleh dengan sebutan baik dan sangat baik, maka akan merupakan suatu peluang bagi perusahaan, tetapi apabila yang diperoleh dengan sebutan kurang baik dan sangat kurang baik, maka hal tersebut merupakan ancaman.

Rangkuti (2015) mendefinisikan "analisis SWOT adalah identifikasi berbagai faktor secara sistematis untuk merumuskan strategi perusahaan. Analisis ini didasarkan pada logika yang dapat memaksimalkan kekuatan (strengths) dan peluang (opportunities), namun secara bersamaan dapat meminimalkan kelemahan (weaknesses) dan ancaman (threats)". Setelah mendapatkan hasil berikutnya adalah penulisan laporan dan proses diseminasi hasil penelitian dalam bentuk publikasi jurnal dan konferensi.

\section{Hasil dan Pembahasan}

Berdasarkan hasil kajian literatur dan diskusi dengan beberapa ahli industri perhotelan di Batam, diidentifikasi 18 faktor internal dan 14 faktor eksternal sebagai berikut:

1) Faktor Internal

- Kelengkapan fasilitas dalam kamar hotel

- Kelengkapan fasilitas hotel

- Fasilitas bermain untuk anak dan keluarga

- Kebersihan kamar hotel

- Kebersihan hotel

- Keterjangkauan lokasi hotel

- Kedekatan hotel dengan daerah wisata dan fasilitas umum

- Penampilan staff hotel

- Keramahan staff hotel

- Kecepatan layanan hotel

- Website hotel yang selalu update informasi

- Harga yang kompetitif

- Adanya sistem informasi manajemen hotel

- Motivasi pekerja

- Komitmen pemilik hotel untuk kemajuan hotel

- Kemampuan keuangan hotel untuk operasional

- Usia bangunan hotel

- Kualitas makanan dan minuman hotel 
2) Faktor Eksternal

- Penggunaan smartphone yang semakin berkembang

- Data internet yang terjangkau

- Situasi pandemik COVID-19

- Persaingan industri hotel

- Kebijakan TCA (Travel Corridor Arrangement) untuk wisatawan asing

- Kegiatan-kegiatan kebudayaan dan pariwisata di kota Batam

- Berkembangnya alternatif penginapan selain hotel

- Banyaknya situs pencarian hotel

- Berkembangnya penggunaan sosial media untuk mereview produk dan layanan

- Kebijakan pajak hotel

- Lokasi strategis kota Batam

Setelah mengidentifikasi faktor internal dan faktor eksternal, maka dilakukan penyebaran kuesioner online kepada para pekerja di sektor perhotelan Batam. Sebanyak 54 responden telah mengisi kuesioner dengan lengkap dan benar. Hasil rekapitulasi data dapat dilihat pada laporan penelitian ini.

Profil responden berdasarkan data demografinya antara lain: jenis kelamin, pendidikan, divisi/badian, dan lama bekerja di industri hotel ditunjukkan pada gambar di bawah ini.

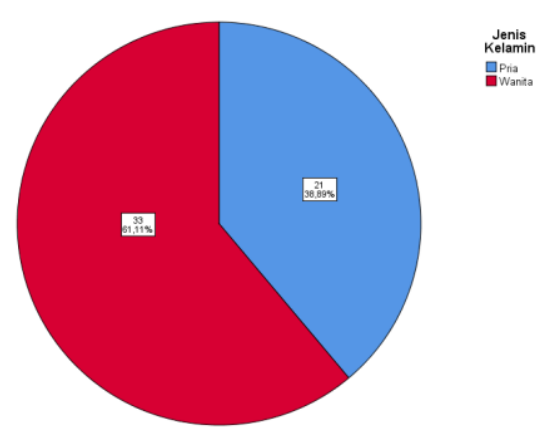

\section{Gambar 1. Profil Responden}

Berdasarkan gambar di atas dapat dilihat bahwa sebagian besar responden berjenis kelamin wanita (33 orang/61,11\%), sedangkan responden pria berjumlah 21 orang $(38,89 \%)$.

\section{Seleksi Faktor Internal dan Faktor Eksternal}

Hasil bobot faktor internal setelah diurutkan

\begin{tabular}{|c|c|c|}
\hline Faktor & Bobot & Urutan \\
\hline Kebersihan hotel & 3,78 & 1 \\
\hline $\begin{array}{l}\text { Kualitas makanan dan } \\
\text { minuman hotel }\end{array}$ & 3,76 & 2 \\
\hline $\begin{array}{ll}\begin{array}{l}\text { Kebersihan } \\
\text { hotel }\end{array} & \text { kamar } \\
\end{array}$ & 3,74 & 3 \\
\hline $\begin{array}{l}\text { Kelengkapan fasilitas } \\
\text { hotel }\end{array}$ & 3,72 & 4 \\
\hline Keramahan staff hotel & 3,72 & 5 \\
\hline $\begin{array}{ll}\text { Kecepatan } & \text { layanan } \\
\text { hotel } & \end{array}$ & 3,70 & 6 \\
\hline $\begin{array}{lr}\text { Website hotel yang } \\
\text { selalu } \\
\text { informasi }\end{array}$ & 3,70 & 7 \\
\hline $\begin{array}{l}\text { Kemampuan } \\
\text { keuangan hotel untuk } \\
\text { operasional }\end{array}$ & 3,67 & 8 \\
\hline $\begin{array}{l}\text { Kelengkapan fasilitas } \\
\text { dalam kamar hotel }\end{array}$ & 3,67 & 9 \\
\hline $\begin{array}{l}\text { Komitmen pemilik } \\
\text { hotel untuk kemajuan } \\
\text { hotel }\end{array}$ & 3,65 & 10 \\
\hline Motivasi staff hotel & 3,65 & 11 \\
\hline Penampilan staff hotel & 3,61 & 12 \\
\hline Harga yang kompetitif & 3,59 & 13 \\
\hline $\begin{array}{lr}\text { Adanya } & \text { sistem } \\
\text { informasi } & \text { manajemen } \\
\text { hotel } & \\
\end{array}$ & 3,52 & 14 \\
\hline $\begin{array}{l}\text { Keterjangkauan lokasi } \\
\text { hotel }\end{array}$ & 3,50 & 15 \\
\hline $\begin{array}{l}\text { Kedekatan hotel } \\
\text { dengan daerah wisata } \\
\text { dan fasilitas umum }\end{array}$ & 3,46 & 16 \\
\hline Usia bangunan hotel & 3,41 & 17 \\
\hline 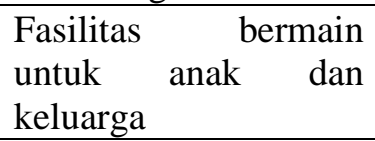 & 3,31 & 18 \\
\hline
\end{tabular}

Dari proses wawancara lebih lanjut dengan beberapa orang ahli perhotelan, akhirnya disepakati 14 faktor internal saja yang relevan bagi industri perhotelan batam, yang dipilih berdasarkan urutan bobotnya. Oleh karena itu, faktor internal: Keterjangkauan lokasi hotel, Kedekatan hotel dengan daerah wisata dan fasilitas umum, usia bangunan hotel, dan fasilitas bermain untuk anak dan keluarga akan dibuang dan tidak dimasukkan dalam analisis SWOT.

Hasil bobot faktor eksternal setelah diurutkan 


\begin{tabular}{|c|c|c|}
\hline Faktor & Bobot & Urutan \\
\hline $\begin{array}{l}\text { Penggunaan } \\
\text { smartphone yang } \\
\text { semakin berkembang }\end{array}$ & 3,70 & 1 \\
\hline $\begin{array}{l}\text { Data internet yang } \\
\text { terjangkau }\end{array}$ & 3,69 & 2 \\
\hline $\begin{array}{l}\text { Lokasi strategis kota } \\
\text { Batam }\end{array}$ & 3,65 & 3 \\
\hline $\begin{array}{l}\text { Berkembangnya } \\
\text { penggunaan sosial } \\
\text { media untuk } \\
\text { mereview produk dan } \\
\text { layanan }\end{array}$ & 3,63 & 4 \\
\hline $\begin{array}{ll}\text { Banyaknya } & \text { situs } \\
\text { pencarian hotel } & \\
\end{array}$ & 3,57 & 5 \\
\hline $\begin{array}{l}\text { Persaingan industri } \\
\text { hotel }\end{array}$ & 3,43 & 6 \\
\hline $\begin{array}{l}\text { Situasi pandemik } \\
\text { COVID-19 }\end{array}$ & 3,41 & 7 \\
\hline $\begin{array}{l}\text { Kegiatan-kegiatan } \\
\text { kebudayaan dan } \\
\text { pariwisata di kota } \\
\text { Batam }\end{array}$ & 3,37 & 8 \\
\hline Kebijakan pajak hotel & 3,35 & 9 \\
\hline $\begin{array}{lr}\text { Kebijakan } & \text { TCA } \\
\text { (Travel Corridor } \\
\text { Arrangement) untuk } \\
\text { wisatawan asing }\end{array}$ & 3,33 & 10 \\
\hline $\begin{array}{l}\text { Berkembangnya } \\
\text { alternatif penginapan } \\
\text { selain hotel }\end{array}$ & 3,33 & 11 \\
\hline
\end{tabular}

Adapun wawancara yang dilakukan lebih lanjut dengan beberapa orang ahli perhotelan, akhirnya disepakati 9 faktor eksternal saja yang relevan bagi industri perhotelan batam, yang dipilih berdasarkan urutan bobotnya. Oleh karena itu, faktor eksternal: Kebijakan TCA (Travel Corridor Arrangement) untuk wisatawan asing dan Berkembangnya alternatif penginapan selain hotel akan dibuang dan tidak dimasukkan dalam analisis SWOT.

Setelah mendapatkan 14 faktor internal dan 9 faktor internal, maka dilakukan pembagian faktor internal menjadi kekuatan dan kelemahan yang dilakukan dengan melihat rating/penilaiannya (kinerja hotel terhadap setiap faktor internal). Demikian juga dilakukan pembagian faktor eksternal menjadi peluang dan ancaman. Tabel bobot dan rating dari faktor internal (kekuatan dan kelemahan) dan faktor eksternal (peluang dan ancaman) ditunjukkan pada tabel di bawah ini.

\begin{tabular}{|c|c|c|c|}
\hline $\begin{array}{c}\text { Faktor } \\
\text { Internal }\end{array}$ & Indikator & Bobot & Rating \\
\hline \multirow{9}{*}{ Kekuatan } & $\begin{array}{l}\text { Kualitas } \\
\text { makanan dan } \\
\text { minuman hotel }\end{array}$ & 3,76 & 4,74 \\
\hline & $\begin{array}{l}\text { Kebersihan } \\
\text { kamar hotel }\end{array}$ & 3,74 & 4,78 \\
\hline & $\begin{array}{l}\text { Keramahan } \\
\text { staff hotel }\end{array}$ & 3,72 & 4,96 \\
\hline & $\begin{array}{l}\text { Kecepatan } \\
\text { layanan hotel }\end{array}$ & 3,70 & 4,76 \\
\hline & $\begin{array}{lr}\text { Website } & \text { hotel } \\
\text { yang } & \text { selalu } \\
\text { update } & \\
\text { informasi } & \\
\end{array}$ & 3,70 & 4,85 \\
\hline & $\begin{array}{l}\text { Kelengkapan } \\
\text { fasilitas dalam } \\
\text { kamar hotel }\end{array}$ & 3,67 & 4,74 \\
\hline & $\begin{array}{l}\text { Komitmen } \\
\text { pemilik hotel } \\
\text { untuk } \\
\text { kemajuan hotel }\end{array}$ & 3,65 & 5,02 \\
\hline & $\begin{array}{l}\text { Penampilan } \\
\text { staff hotel }\end{array}$ & 3,61 & 4,91 \\
\hline & $\begin{array}{l}\text { Adanya sistem } \\
\text { informasi } \\
\text { manajemen } \\
\text { hotel }\end{array}$ & 3,52 & 4,87 \\
\hline \multirow{5}{*}{ Kelemahan } & $\begin{array}{l}\text { Motivasi staff } \\
\text { hotel }\end{array}$ & 3,65 & 4,69 \\
\hline & $\begin{array}{l}\text { Harga yang } \\
\text { kompetitif }\end{array}$ & 3,59 & 4,72 \\
\hline & $\begin{array}{l}\text { Kebersihan } \\
\text { hotel }\end{array}$ & 3,78 & 4,72 \\
\hline & $\begin{array}{l}\text { Kelengkapan } \\
\text { fasilitas hotel }\end{array}$ & 3,72 & 4,65 \\
\hline & $\begin{array}{l}\text { Kemampuan } \\
\text { keuangan hotel } \\
\text { untuk } \\
\text { operasional }\end{array}$ & 3,67 & 4,67 \\
\hline
\end{tabular}

\begin{tabular}{|c|c|c|c|}
\hline $\begin{array}{c}\text { Faktor } \\
\text { Eksternal }\end{array}$ & Indikator & Bobot & Rating \\
\hline \multirow{5}{*}{ Peluang } & $\begin{array}{l}\text { Penggunaan } \\
\text { smartphone yang } \\
\text { semakin } \\
\text { berkembang } \\
\end{array}$ & 3,70 & 5,00 \\
\hline & $\begin{array}{l}\text { Data internet } \\
\text { yang terjangkau }\end{array}$ & 3,69 & 5,06 \\
\hline & $\begin{array}{l}\text { Lokasi strategis } \\
\text { kota Batam }\end{array}$ & 3,65 & 4,85 \\
\hline & $\begin{array}{l}\text { 3erkembangnya } \\
\text { penggunaan } \\
\text { sosial media } \\
\text { untuk mereview } \\
\text { produk dan } \\
\text { layanan }\end{array}$ & 3,63 & 4,83 \\
\hline & $\begin{array}{lr}\text { Kegiatan- } & \\
\text { kegiatan } & \\
\text { kebudayaan } & \text { dan } \\
\text { pariwisata } & \text { di } \\
\text { kota Batam } & \\
\end{array}$ & 3,37 & 4,00 \\
\hline Ancaman & Banyaknya situs & 3,57 & 4,65 \\
\hline
\end{tabular}




\begin{tabular}{|l|l|c|c|}
\hline & pencarian hotel & & \\
\cline { 2 - 4 } & $\begin{array}{l}\text { Persaingan } \\
\text { industri hotel }\end{array}$ & 3,43 & 3,96 \\
\cline { 2 - 4 } & $\begin{array}{l}\text { Situasi pandemik } \\
\text { COVID-19 }\end{array}$ & 3,41 & 3,52 \\
\cline { 2 - 4 } & $\begin{array}{l}\text { Kebijakan pajak } \\
\text { hotel }\end{array}$ & 3,35 & 4,41 \\
\hline
\end{tabular}

\section{Kesimpulan}

Dalam penelitian yang telah peneliti lakukan yang bertujuan untuk memberikan kontribusi terhadap peningkatan kemampuan strategi pemasaran dengan menggunakan teknologi informasi menunjukkan hasil yang cukup baik. Dalam beberapa aspek terlihat ada yang menunjukkan tidak terlalu signifikan, namun respon terhadap penggunaan teknologi informasi sebagai alat bantu untuk peningkatan kemampuan strategi pemasaran mendapatkan respon yang positif yang berjalan lurus dengan penelitian sebelumnya. Perspektif responden terhadap teknologi informasi mampu meningkatkan kemampuan strategi pemasaran pada bisnis perhotelan. Secara keseluruhan masih mendapatkan respon yang cukup positif terkait pengaruh teknologi informasi pada bisnis perhotelan, namun untuk mengetahui seberapa jauh teknologi informasi pada peningkatan bisnis perhotelan msaih diperlukan penelitian lebih lanjut.

\section{Daftar Pustaka}

[1] Ahyuna, Hamzah, M. D., \& HM Najib, M. (2013). Pemanfaatan Internet Sebagai Media Promosi Pemasaran Produk Lokal oleh Kalangan Usaha di Kota Makassar

[2] Atmoko, T. P. H. (2018). Strategi Pemasaran untuk Meningkatkan Volume Penjualan di Cavinton Hotel Yogyakarta.

[3] Himawan, P. A., \& Astuti, T. (2017). Perencanaan Strategis Sistem Informasi dan Teknologi Informasi Pemasaran dan Pelayanan pada Hotel (Studi Kasus: Grand Kanaya Baturraden)

[4] Komar, R. (2014). Hotel Management. Jakarta: PT. Grasindo

[5] Rangkuti, Freddy., 2015. Analisis SWOT Tehnik Membedah Kasus Bisnis. PT. Gramedia Pustaka Utama. Jakarta

[6] Rufaidah, Popy. (2014). Manajemen Strategik. Edisi Revisi. Bandung: Buku Pendidikan - Anggota IKAPI.

[7] Sunyoto, Danang. (2015). Strategi Pemasaran, Konsep Memenangkan Persaingan Bisnis dan Menakar Keberhasilan Strategi Menarik Konsumen. Yogyakarta: CAPS (Center for Academic Publishing Service).

[8] Widiyanto, I., \& Prasilowati, S. L. (2015). Perilaku pembelian melalui internet,17(2), 109-112. https://doi.org/10.9744/jmk.17.2.109

[9] Wijaya, C. P., \& Santoso, T. P. B. (2018). Strategi pemasaran dalam meningkatkan tingkat hunian kamar pada hotel Bali Mandira Legian - Bali 